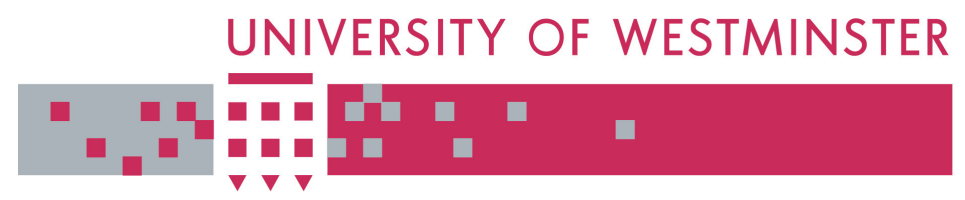

\title{
WestminsterResearch
}

http://www.wmin.ac.uk/westminsterresearch

\section{The future of disparate impact in Britain and the United States: shoot the Wards Cove quota myth and recognize plantation economy cases.}

\section{Michael Connolly}

Westminster Business School

This is an electronic version of an article published in the International Journal of Diversity in Organisations, Communities and Nations, 4, 2006. Readers must contact the publisher, Common Ground for permission to reproduce this article. The article is available online at:

http://ijd.cgpublisher.com/product/pub.29/prod.71

The WestminsterResearch online digital archive at the University of Westminster aims to make the research output of the University available to a wider audience. Copyright and Moral Rights remain with the authors and/or copyright owners. Users are permitted to download and/or print one copy for non-commercial private study or research. Further distribution and any use of material from within this archive for profit-making enterprises or for commercial gain is strictly forbidden.

Whilst further distribution of specific materials from within this archive is forbidden, you may freely distribute the URL of WestminsterResearch.

(http://www.wmin.ac.uk/westminsterresearch). 


\section{International Journal of Diversity in Organisations, Communities and Nations}

Volume 4

Article: DC04-0023-2004

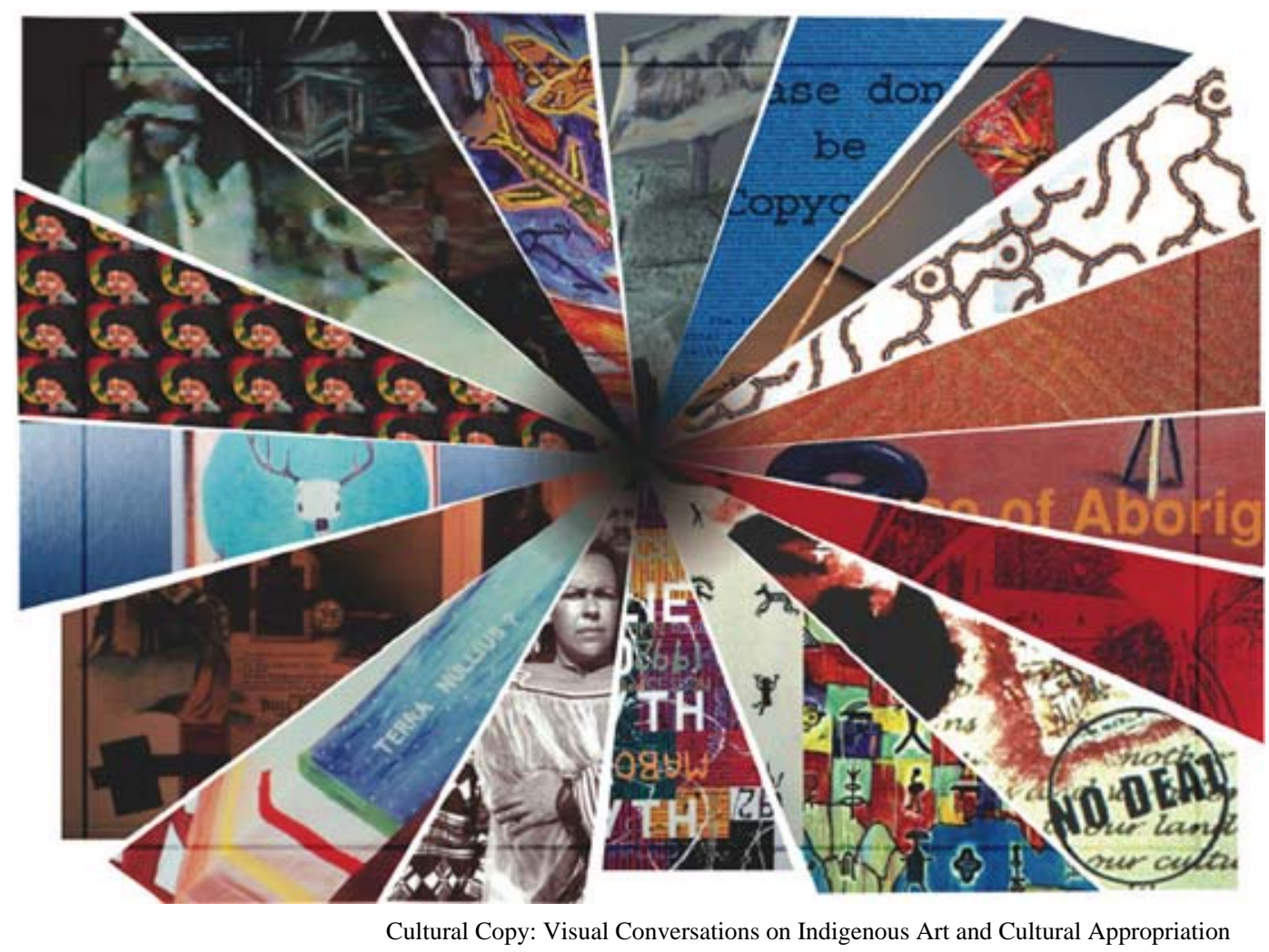

\section{The Future of Disparate Impact in Britain and the United States}

Shoot the Wards Cove Quota Myth and Recognize Plantation Economy

Cases

Michael Connolly, Senior Lecturer in Law, Westminster Business School, University of Westminster, London, United Kingdom 



\title{
International Journal of Diversity in Organisations, Communities and Nations, Volume 4
}

\author{
‘Cultural Copy’ Acknowledgements
}

Cover Image: ‘Cultural Copy’ Exhibition and Diversity Conference Plenary Session

Graphic Design: Alesia Massey. Image courtesy of BorderZone Arts, Inc.

'Cultural Copy’ Exhibition, UCLA Fowler Museum of Cultural History, USA

July 7 to September 12th, 2004

Launched as part of the Diversity Conference 2004

BorderZone Arts Inc., Common Ground, The Globalism Institute, RMIT University, Australia

Exhibit Designer: Marco Centin

Curators: Tressa Berman, Marie Bouchard, Jennifer Herd

Curatorial Associates: Vivien Johnson, Matt McKinley, Fred Nahwooksy,

Exhibiting Artists: Richard Bell, Jennifer Herd, Kathleen Petyarre with Ray Beamish, Fiona Foley, Gordon Syron, Vernon Ah Kee, Michael Eather and Michael Nelson Jagamarra, Jenny Fraser, Frank LaPena, Arthur Amiotte, Anthony White, Colleen Cutschall, Nora Naranjo-Morse, Greg Hill, Jaune Quick-to-See-Smith, Sam Toonoo, Roger Crait

The Cultural Copy exhibition was made possible by the generous support of the National Endowment for the Arts, the California Council for the Humanities, The Christensen Fund, Rio Tinto, Canadian Consulate General, Los Angeles, Art Gallery of Southwest Manitoba, Fireworks Gallery and the UCLA Fowler Museum of Cultural History.

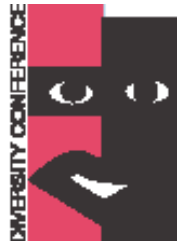

www.DiversityConference.com

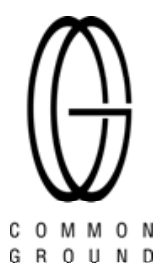

www.CommonGroundGroup.com 
This journal and individual papers published at www.Diversity-Journal.com a series imprint of theUniversityPress.com

First published in Australia in 2004/2005 by Common Ground Publishing Pty Ltd at www.Diversity-Journal.com

Selection and editorial matter copyright (C Common Ground 2004/2005

Individual papers copyright (c) individual contributors 2004/2005

All rights reserved. Apart from fair dealing for the purposes of study, research, criticism or review as permitted under the Copyright Act, no part of this book may be reproduced by any process without written permission from the publisher.

ISSN 1447-9532 (Print)

ISSN 1447-9583 (Online)

The International Journal of Diversity in Organisations, Communities and Nations is a peer-refereed journal which is published annually. Full papers submitted for publication are refereed by the Associate Editors through an anonymous referee process.

Papers presented at the Fourth International Conference on Diversity in Organisations, Communities and Nations, held at the University of California Los Angeles, 6-9 July 2004. 


\section{Editors}

Mary Kalantzis, Innovation Professor, RMIT University, Melbourne, Australia.

Paul James, Globalism Institute, RMIT University, Melbourne, Australia.

\section{Diversity Conference Advisory Committee and Editorial Advisory Board of the International Journal of Diversity in Organisations, Communities and Nations}

Andrew Jakubowicz, Faculty of Humanities, Faculty of Humanities and Social Sciences, University of Technology, Sydney, Australia.

Jock Collins, Faculty of Business, University of Technology, Sydney, Australia.

Geoff Stokes, Institute for Citizenship and Globalisation, Deakin University, Melbourne, Australia.

Brendan O'Leary, Solomon Asch Center for the Study of Ethnopolitical Conflict, University of Pennsylvania, USA.

Samuel Aroni, University of California, Los Angeles, USA.

James Early, Smithsonian Institution, Washington, DC, USA.

Peter Sellars, Theatre, Opera and Film Director.

Barry Gills, University of Newcastle, UK.

Walter Mignolo, Duke University, USA.

Ien Ang, University of Western Sydney, Australia.

Michael Shapiro, University of Hawai'i, USA.

Duane Champagne, University of California, Los Angeles, USA.

Peter McLaren, University of California, Los Angeles, USA.

Owens Wiwa, African Environmental and Human Development Agency, Toronto, Canada.

Jackie Huggins, Aboriginal and Torres Strait Islander Studies Unit, University of Queensland, Australia.

Mililani Trask, Indigenous Expert to the Permanent Forum on Indigenous Issues for the Economic Council of the UN Assembly, Hawai'i, USA.

Armareswar Galla, Australian National University, Canberra, Australia.

Guosheng Y. Chen, Chinese Australian Studies Forum, RMIT University, Melbourne, Australia.

Peter Phipps, Globalism Institute, RMIT University, Melbourne, Australia.

Bill Cope, Common Ground and Visiting Fellow, Globalism Institute, RMIT University, Australia. 



\title{
The Future of Disparate Impact in Britain and the United States
}

\author{
Shoot the Wards Cove Quota Myth and Recognize Plantation \\ Economy Cases
}

Michael Connolly, Senior Lecturer in Law, Westminster Business School, University of Westminster, London, United Kingdom

\begin{abstract}
"Librarians wanted - applicants must be over six feet tall" is a subtle way of achieving a discriminatory goal. Since the seminal case of Griggs v Duke Power,* decided by a unanimous Supreme Court in 1971, the United States judiciary has, using disparate impact theory, recognised such cases as legally actionable. Case law also recognised some (but not all) discriminatory subjective hiring practices (such as excessive discretion given to one manager), but stopped short, in Wards Cove v Atonio,** of recognising "plantation economy" cases, where there is a racially stratified workforce with no identified specific cause.

In the meantime, the British Parliament followed Griggs by outlawing indirect discrimination in the Sex Discrimination Act 1975 and the Race Relations Act 1976. However, after some deference to the spirit of Griggs in the early years, the British judiciary gave the statutory definition the narrowest interpretation. So much so, that in recent years, a new statutory definition was introduced to reverse the effect of these cases. In liberalising the law, the new definition opens the way to challenge subjective hiring practices, and possibly the plantation economy cases that were rejected in Wards Cove. For the first time British anti-discrimination law has the opportunity of advancing on its American model. Central to this is overcoming the objections made in Wards Cove. The underlying and surviving reasoning of the Wards Cove decision is that to recognise these cases would force employers to adopt quotas. This paper will show that all discriminatory subjective hiring practices should be actionable and that the Wards Cove quota reasoning is technically flawed and a fiction. Further, it will demonstrate positive reasons why plantation economy cases should be recognised.

* 401 US 424 (1971).

** 490 US 642 (1989).
\end{abstract}

Keywords: Disparate Impact/Indirect Discrimination, Plantation Economies, Quota Fear, Subjective Hiring Practices, New Definitions of Disparate Impact, Wards Cove v Atonio, Griggs v Duke Powe, Perera v Civil Service Commission.

\section{Introduction}

The European Union has forced Britain to introduce a more liberal definition of indirect discrimination law, giving the judiciary more scope for interpretation. United States judges have been interpreting an open-ended definition since 1964. This paper explores the possibilities of the new British definition by reviewing the American experience.

In 1971, the Supreme Court, in Griggs $v$ Duke Power Co, ${ }^{1}$ outlawed indirect discrimination by developing disparate impact theory. Title VII, Civil Rights Act 1964, provides: $^{2}$

"It shall be an unlawful employment practice for an employer - (1) to fail or refuse to hire or to discharge any individual, or otherwise to discriminate against any individual ... because of

\footnotetext{
401 US 424 (1971)

${ }^{2}$ Section 703(a) (codified as 42 USCS s. 2000e-2).
}

such individual's race, color, religion, sex or national origin..."

Duke Power's Station in North Carolina was divided into five departments: Labor, Coal Handling, Operations, Maintenance, and Laboratory and Test. Work in the Labor Department was the dirtiest and lowest paid. A high school diploma and/or the passing of an intelligence test was necessary to gain employment in, or promotion to, any of the four other Departments. Duke Power employed 95 workers at the Station, 14 of whom were African-Americans. All 14 African-Americans were employed in the Labor Department. Statistics revealed that 34 per cent of whites completed high school, in contrast to 12 per cent of AfricanAmericans. Research showed that 58 per cent of whites, in contrast to six per cent of AfricanAmericans, passed the Intelligence Tests used by Duke Power. Duke Power showed they had not intended that the requirements would discriminate, but failed to show that the requirements were related to job performance. The Supreme Court found Duke 
Power liable under Title VII and gave its reasoning this short, classic, paragraph:

"Congress has now provided that tests or criteria for employment or promotion may not provide equality of opportunity merely in the sense of the fabled offer of milk to the stork and the fox. On the contrary, Congress has now required that the posture and condition of the job-seeker be taken into account. It has - to resort again to the fable provided that the vessel in which the milk is proffered be one all seekers can use. The Act proscribes not only overt discrimination but also practices that are fair in form, but discriminatory in operation. The touchstone is business necessity. If an employment practice which operates to exclude [African-Americans] cannot be shown to be related to job performance, the practice is prohibited."3

It can be seen that this disparate impact theory has two broad limbs. First, the plaintiff identifies a disparate impact upon his or her racial group, caused by the defendant. The defendant then has the opportunity to "justify" that disparity with matters related to job necessity.

However, the certainty of this theory was disturbed by the 1989 case, Wards Cove $v$ Atonio, ${ }^{4}$ and the legislation that followed. Wards Cove ran salmon canneries in Alaska where skilled (mainly white) and unskilled (mainly Filipino or native Alaskan) workers were divided by separate accommodation, dining halls and pay. A class of non-white unskilled workers brought a case - heavily based on statistical evidence - of disparate impact. A bare majority of the Supreme Court rejected the claim.

The majority held that a plaintiff had to isolate each specific, identifiable employment practice that caused a disparate impact. They also rejected the plaintiff's "in-house" statistics, stating that the proper comparison was between the at-issue jobs (the skilled jobs) and the relevant labour market. For this and other reasons, the decision caused uproar and confusion, leaving Congress to clarify the law. The problem for Congressional reform was summed up by White, J, who stated that an alternative result would mean that any employer with a racially imbalanced workforce could be "haled into court" to justify to the situation. ${ }^{5}$ The alternative was to hire in quotas. Congress passed section 105 of the Civil Rights Act 1991, which provided that:

"...the complaining party shall demonstrate that each particular challenged employment practice causes a disparate impact...”

This Follows the Wards Cove Line. However, the Reform came with the Exception

\footnotetext{
${ }^{3}$ Per Berger, CJ, 401 US 424, at 434.

${ }^{4} 490$ US 642 (1989).

${ }^{5}$ Ibid., at 652 .
}

“...if the complaining party can demonstrate to the court that the elements of a respondent's decisionmaking [sic] process are not capable of separation for analysis, the decisionmaking process may be analyzed as one employment practice."

The Legislative History was Restricted to Just One Statement

"When a decision-making process includes particular, functionally-integrated practices which are components of the same criterion, standard, method of administration, or test, such as the height and weight requirements designed to measure strength in Dothard $v$ Rawlinson ${ }^{7}$ the particular, functionally-integrated practices may be analysed as one employment practice"

The requirements in Dothard $v$ Rawlinson were designed to measure the strength of prison officer applicants, but discriminated against women. According to the exception, these requirements could not be separated for analysis and so could be taken as a whole when linking them to the disparate impact upon women. The Wards Cove ruling on the comparison was left unaffected by Congress.

In the meantime, Britain suffered under an even more restrictive definition. Section 1 of the Race Relations Act 1976 (RRA 1976) provided:

“(1) (b) A person discriminates against another...if-...

(b) he applies to that other a requirement or condition which he applies or would apply equally to persons not of the same racial group as that other but-

(i) which is such that the proportion of persons of that same racial group who can comply with it is considerably smaller than the proportion of persons not of that racial group who can comply with it, and

(ii) which he cannot show to be justifiable..."9

The key phrase here is "requirement or condition." In Perera v Civil Service Commission, ${ }^{10}$ the Court of Appeal held that the formula could apply only to discriminatory measures that amounted to absolute barriers to a job, rather than "mere preferences" that put people at a disadvantage, because of race or sex. So, a job advertisement reading "applicants over six feet tall would be preferred" would fall outside of the legislation, under this interpretation. ${ }^{11}$ Only if the

\footnotetext{
${ }^{6} 42$ USCS s. 2000e-2(k) (1)(B)(i). The majority's opinion on justification was reversed by the 1991 Civil Rights Act, which restored the law to the pre-Wards Cove position. See 42 USCS s. $2000 \mathrm{e}-2,(\mathrm{k})(1)(\mathrm{A})(\mathrm{i})$

${ }^{7} 433$ US 321 (1977).

${ }^{8}$ Per Sen Danforth, 137 Cong Rec S15276 (daily ed Oct 25, 1991).

${ }^{9}$ Section 1(1)(b), sex Discrimination Act 1975 is materially the same.

${ }^{10}$ [1983] ICR 428 CA. Followed in Meer v London Borough of Tower Hamlets[1988] IRLR 399, CA.

${ }^{11}$ Contrast the Australian case, Styles (1989) 88 ALR 621. Of course, it was open to the Court of Appeal to hold that such
} 
preference were elevated to a requirement ("applicants must be over six feet tall") would the Act apply.

However, Britain was forced by successive European Directives ${ }^{12}$ to liberalise the formula. The new definition reads:

"A person ... discriminates against another if ... he applies to that other a provision, criterion or practice which he applies or would apply equally to persons not of the same race or ethnic or national origins as that other, but

1. which puts or would put persons of the same race or ethnic or national origins as that other at a particular disadvantage when compared with other persons,

2. which puts that other at a disadvantage, and

3. which he cannot show to be a proportionate means of achieving a legitimate aim." 13

By replacing the phrase "requirement or condition" with "provision, criterion or practice" the new definition is open to many more types of indirect discrimination. It may even have potential beyond its (reformed) American counterpart.

For the present purposes, disparate impact cases may be divided into three classes. (1) Subjective hiring practices, such as excessive discretion conferred upon one person, say a foreman, which perpetuates a workplace situation, eg racially imbalanced workforce. (2) "Plantation economy" cases, where there is a racially stratified workforce with no identified specific cause. (3) A neutral requirement, such as the tests in Griggs. This third class of cases is challengeable under both US and UK legislation. Whether or not the first two classes are challengeable demands further inquiry.

\section{Subjective Hiring Practices}

Normally, subjective hiring practices have been actionable in the United States. For example, in Rowe v General Motors, ${ }^{14}$ production line staff were hourly paid whilst foremen and management were salaried. To be promoted from the production a worker line either needed to have the foreman's recommendation, or take the initiative in the hope that there was a vacancy at the time. The Court identified the following features: ${ }^{15}$

preferences were in fact "requirements to gain an advantage." For other arguments suggesting that Perera was incorrectly decided see, Connolly, M, "Discrimination law: requirements and preferences," [1998] Industrial Law Journal 133.

${ }^{12}$ Burden of Proof Directive, Council Directive 97/80/EC (sex); Race Directive, Council Directive 2000/43/EC.

${ }^{13}$ Section 1(1A), RRA 1976; Section 1(1A), SDA 1975 is materially the same. In force (RRA) 19 July 2003, (SDA) 12 October 2001

${ }^{14} 457$ F 2d 348 (1972) (CA 5th). See also, Montana Rail Link v Byard 260 Mont 331 (1993) (Supreme Court of Montana).

${ }^{15} \mathrm{Ibid}$, at $358-359$.
1. The foreman's recommendation (in either case) was vital.

2. The foreman was given no written instructions regarding qualifications necessary for promotion.

3. His criteria used were vague and subjective: "ability, merit, capacity, experience, attendance, and medical and disciplinary records." In fact, the records were never checked. Seniority was not a factor.

4. Hourly employees were not notified of promotion opportunities or the qualifications necessary to get jobs.

5. There were no safeguards in this "procedure" designed to avert discriminatory practices.

It was held that this "procedure" amounted to an employment practice within Title VII, and that it discriminated against African-Americans, who occupied predominantly the hourly jobs.

A more recent and prominent example arose in the Supreme Court in Watson v Fort Worth Bank and Trust, ${ }^{16}$ where the African-American applicant was rejected for promotion to supervisory positions in the bank. The employers had no formal criteria for the position, but relied on the subjective judgment of white supervisors. It was held that the doctrine of disparate impact could be applied to challenge such a subjective procedure. O'Connor, J stated: ${ }^{17}$

"We are also persuaded that disparate impact analysis is in principle no less applicable to subjective employment criteria than to objective or standardised tests. In either case, a facially neutral practice, adopted without discriminatory intent, may have effects that are indistinguishable from intentionally discriminatory practices ...”

The question now is whether these claims would survive the reforms in the 1991 Civil Rights Act. Clearly it would be very difficult - if not impossible - for the plaintiffs in Rowe to prove each criterion caused a disparate impact. Presumably, a court would hold that they were "functionally-integrated practices" and so may be analysed as one employment practice, under section 105's exception. An example arising after the Act is Butler $v$ Home Depot $^{18}$ where "sociological and anecdotal" evidence showed that a male culture dominated the working environment and allowed stereotypes about women to prevail. For the selection and promotion of staff there was a near total absence of specific criteria, no written guidelines, no jobs advertised, no formal procedure for discovering vacancies and no reasons given for promotion decisions. The Court

\footnotetext{
${ }^{16} 487$ US 977 (1988), US Supreme Court.

${ }^{17} \mathrm{Ibid}$, at $989-991$.

${ }^{18} 1997$ US Dist LEXIS 16296 District Court for the Northern District of California.
} 
held that the defendant's recruitment and promotion practices could be analysed as a whole. ${ }^{19}$

However, it would seem that there is a sub-class of cases that are not actionable. The common feature in these cases is that the employer merely acquiesced in the informal procedures. In Ballor $v$ Alcona County Road Commission ${ }^{20}$ the plaintiff complained that the word-of-mouth and walk-in recruitment practices of the defendant had a disparate impact upon women. The defendant did not positively encourage this "system." It was held that this nonaction - cast by the court as the plaintiff's "failureto-recruit theory" - did not amount to a "practice" under disparate impact theory. ${ }^{21}$ The Court relied on EEOC $v$ Chicago Miniature Lamp Works, ${ }^{22}$ where it was held that if an employer did not actively encourage word-of-mouth recruitment, it was not possible to identify a specific employment practice as causing adverse impact. ${ }^{23}$

Ballor and Chicago Miniature Lamp Works are suspect because there seems to be no reason or principle why an employer's acquiescence in discrimination should be lawful. After all, on general tortious principles, an omission amounts to an act. This also sidesteps any notion of vicariously liability. (Why should not an employer be liable for a discriminatory practice operated by his worker?) If a particular culture dominates the working environment, that culture will prevail in recruitment, unless some active steps are taken to counter it. To distinguish cases purely on the ground that in one, the employer instructed staff to discriminate, whilst in the other, he sat back and observed his staff do it, must be against the policy of the legislation and brings the law into disrepute. Further, it goes dangerously close to suggesting that liability is faultbased, which it is not. ${ }^{24}$ In any case, it is inconceivable that nowadays an employer would be unaware that an informal recruitment policy would, at the least, perpetuate the status quo, and most

\footnotetext{
${ }^{19}$ See also Stender v Lucky Stores 803 F Supp 259 (1992) (District Court for the Northern District of California) where the employment practice was held to be a "lack of uniform criteria, criteria that were subjective as well as variable, discretionary placements and promotions, a failure to follow set procedures and the absence of written policies or justifications for promotional decisions." In Caron v Scott Paper 834 F Supp 33 (1993) (District Court for the District of Maine) the employment practice consisted of the subjective factors of: "job skills, leading change skills, interpersonal skills, self-management, performance, and versatility," and the objective factor of "length of service."

${ }^{20}$ No 95-CV-10366-BC (1997) US Dist LEXIS 4337 (US District Court for the Eastern District of Michigan, Northern Division). Affirmed 145 F.3d 1329.

${ }^{21}$ Ibid, at 37.

${ }^{22}$ Equal Employment Opportunities Commission v Chicago Miniature Lamp Works 947 F 2d 292, at 288-89 (CA 7th Cir 1991)

${ }^{23}$ Chicago Miniature was distinguished in Byard v Montana Rail Link because that in Byard the employer was the "impetus" behind the "word-of-mouth" recruitment, whereas in Chicago Miniature it was "employee initiated": 260 Mont, 331 at 352.

${ }^{24}$ Griggs v Duke Power 401 US 424 (1971).
}

likely, discriminate against groups underrepresented in the workplace.

Until recently most subjective employment practices were lawful under Britain's discrimination law because such nebulous criteria rarely amounted to an absolute bar, or "requirement." For instance, in Perera $v$ Civil Service Commission, ${ }^{25}$ the Court of Appeal rejected Mr Perera's argument that several "preferences" (good command of the English language, experience in the UK and British nationality) that could not be complied with, added up to an absolute bar to many of those, like $\mathrm{Mr}$ Perera, of Sri Lankan origin. However, under the new definition, "provision, criterion or practice," subjective practices should be challengeable, especially free from any stricture resembling section 105, Civil Rights Act 1991. However, there are two areas that require clarification. First, the practice must cause a "particular disadvantage" (emphasis supplied). But this is quite different from demanding that each practice is isolated. A claimant should be able to establish that several criteria (amounting to a single practice) caused a particular disadvantage to her group.

The second issue is whether the formula covers "acquiescence" cases, such as Ballor and Chicago Miniature. The only similar British case arose Pel Ltd $v$ Modgill, ${ }^{26}$ a claim of direct discrimination (disparate treatment) under section 1(2), RRA 1976, which provides that "segregating a person from other persons on grounds of race is treating him less favourably than they are treated." In this case a paint shop in a factory was staffed solely by Asians. Originally, there had been white workers there as well. However, over the years as vacancies arose they were filled by friends or relatives of the Asians through word of mouth; the personnel department did no recruiting. The paint spray work was the dirtiest in the factory and the Asians complained alleging segregation. Slynn, J rejected the claim, stating:

“...had there been evidence of a policy to segregate, and of the fact of segregation arising as a result of the company's acts, that might have well constituted a breach of the legislation....We do not consider that the failure of the company to intervene and to assist on white or non-Asian workers going into to the shop, contrary to the wishes of the men to introduce their friends, itself constituted an act of segregating...,27

Slynn, $\mathrm{J}$ is saying, in effect, that there must be a positive act of segregation by the defendant, to fall within the definition given by section 1(2), RRA 1976. In this case, as in Ballor and Chicago Miniature, the employer merely acquiesced in the

\footnotetext{
25 [1983] ICR 428 CA. Followed in Meer v London Borough of Tower Hamlets[1988] IRLR 399, CA.

${ }^{26}$ [1980] IRLR 142 EAT.

27 Ibid, at para 40.
} 
discriminatory practice. But there are doubts over the correctness of such a decision under the British legislation. First section 78, RRA $1976,{ }^{28}$ provides that, for the purposes of the RRA, an act includes a deliberate omission. Second, this was a case of direct discrimination arising before it was settled that discriminatory intent was not an element of direct discrimination. ${ }^{29}$ As discriminatory intent never has been an element of indirect discrimination, a fortiori Pel $v$ Modgill should carry no authority in such cases. At the least, an employer who was aware of the challenged practice should be liable for a "deliberate omission." It would very difficult for an employer, who say, operated no recruitment procedure, to deny awareness of how his workers were recruited. Thus, under the new definition of indirect discrimination, "acquiescence" cases should succeed in Britain.

\section{The Plantation Economy Cases}

The features of these cases are "in-house" statistics revealing a significant disparity in the workforce, and no identified specific employment practice causing the disparity. A conspicuous case here is Wards Cove Packing Co v Atonio. ${ }^{30}$ In Wards Cove it will be recalled, the workforce was divided along racial lines in skills, accommodation, and pay. In his dissent, Stevens, J made this vivid observation:

"... some characteristics of the Alaska salmon industry described in this litigation ... - in particular, the segregation of housing and dining facilities and the stratification of jobs along racial and ethnic lines - bear an unsettling resemblance to aspects of a plantation economy."

The difficulty was that although the situation appears repugnant to modern civilization, the plaintiffs could not isolate particular practices that caused the disparity. The scenario alone was not enough for the majority, who reasoned that a decision in favour of the plaintiffs:

“... would mean that any employer who had a segment of his work force that was - for some reason - racially imbalanced, could be haled into court and forced to engage in the expensive and time-consuming task of [justification] ... The only practicable option for many employers would be to adopt racial quotas ... "31 and "... would result in employers being potentially liable for

\footnotetext{
${ }^{28}$ This is consistent throughout the legislation: SDA 1975, s 82(1); Employment Equality (Religion or Belief) Regulations 2003, SI 2003/1660, reg 2(3); Employment Equality (Sexual Orientation) Regulations 2003, SI 2003/1661, reg 2(3); Disability Discrimination Act 1995, s 68(1).

${ }^{29}$ See R. v Birmingham City Council ex parte EOC [1989] AC 1155 HL, and James v Eastleigh Borough Council [1990] AC 751, HL. ${ }^{30} 490$ US 642 (1989).

${ }^{31}$ Ibid, at 652 .
}

'the myriad of innocent causes that may lead to statistical imbalances in the composition of their work forces."

Of course, the reasoning is based on the fear of quotas. $^{33}$ Before discussing the fundamental objection to the quota fear, it is helpful to consider two technical aspects of the majority's decision: (1) the need to identify a specific causal employment practice and (2) the rejection of the plaintiff's "inhouse" statistics for the comparison.

\section{Specific Identifiable Practice}

The majority demanded that a plaintiff must identify a specific employment practice that caused the disparate impact. The problem with this strict approach is that it is based on the notion that this element serves to prevent quotas. It does not. This can be illustrated by envisaging a crude - or "fairshare" - theory, ${ }^{34}$ that wherever there was a racial imbalance, a successful disparate impact claim would follow. That would drive employers to adopt quotas. The element missing from this notion is "justification." We know that justification can show how far the employer's practice is job-related. What is less obvious is that it can show, in addition, whether the cause is within or without the employer's control, or a proportion of each. For instance, in Enderby $v$ Frenchay Health Authority, ${ }^{35}$ the defendant employer was trying to justify a 40 per cent difference in pay between speech therapists (98 per cent female) and pharmacists (63 per cent female). As women were over-represented in the lower paid group, this was a prime facie case of indirect sex discrimination, which the employer was burdened to justify. The employer argued that market forces caused the difference, although their evidence revealed that only an extra 10 per cent pay was needed to recruit a sufficient number of pharmacists. Thus, there existed a less discriminatory alternative of paying the pharmacists

\footnotetext{
${ }^{32} 490$ US 642, at 657. Citing Watson v Fort Worth Bank \& Trust 487 US 977, at 992.

${ }^{33}$ S 703(j), Civil Rights Act 1964, provides: "Nothing contained in [Title VII] shall be interpreted to require any employer ... to grant preferential treatment to any individual or to any group because of the race, color, religion, sex, or national origin of such individual or group on account of an imbalance which may exist with respect to the total number or percentage of persons of any race $[$ etc] ... employed by any employer ... in comparison with the total number or percentage of persons of such race [etc] ... in any community, State, section, or other area, or in the available work force in any community, State, section, or other area. 42 USCS s. 2000e-2(j). See also Albemarle Paper Co v Moody 422 US 405, at 449 (Blackmun, J, concurring in judgment) (1975).

${ }^{34}$ See Carvin, M, "Disparate Impact Claims Under the New Title VII" 68 Notra Dame Law Rev 1153, who calls this a "pure" standard, at 1154. See also Lustgarten, L, Legal Control of Racial Discrimination, 1980, London: Macmillan Press, who names this "unalloyed" in contrast to the "compromised" statutory theory, at p 54.

35 [1994] 1 All ER 495 ECJ.
} 
a 10 per cent premium. The European Court of Justice stated:

"If...the National Court has been able to determine precisely what proportion of the increase in pay is attributable to market forces, it must necessarily accept that that the pay differential is objectively justified to the extent of that proportion." ${ }^{, 36}$

The point is that in every case there will be a cause of a proven disparate impact. It will be either the employment practice or something outside the control of the employer (say, the skills of the respective racial/gender groups in the labour market), or a proportion of each. In Enderby, the shortage of female pharmacists caused some of the disparate impact, whilst employer discrimination caused the rest. Here justification not only exempted the employer from liability for causes beyond its control, it also identified the causes of all the disparate impact. If this approach were adopted for plantation economy cases, the issue would not be whether or not there should exist an employment practice, but rather, upon whom is the burden of identifying it, which is a very different question, to which we will return presently.

\section{The Comparison}

The Supreme Court in Wards Cove Packing Co v Atonio $^{37}$ emphasised that the usual comparison to be made is between the racial make-up of the at-issue (ie skilled) jobs and the racial make-up of the qualified persons in the labour market. ${ }^{38}$ Alternatively, where labour market statistics are unavailable, statistics indicating the racial composition of otherwise-qualified applicants for the at-issue jobs could be used. ${ }^{39}$ However, this "applicant comparison" has been commonly used, especially where tests are alleged to have a discriminatory impact. ${ }^{40}$ In the sex discrimination case Dothard $v$ Rawlinson ${ }^{41}$ a comparison between men and women of the general population was used, although that was a highly unusual case where height and weight requirements were likely to discriminate against women in any section of the workforce, nation-wide.

The type of comparison used by the plaintiff was a major issue in the Wards Cove case. The plaintiffs argued that a prima facie case of disparate impact was made out with statistics showing a high

\footnotetext{
${ }^{36}$ Ibid, at para 27.

${ }^{37} 490$ US 642 (1989)

${ }^{38} 490$ US 642, at $650-651$.

${ }^{39}$ Eg New York City Transit Authority v Beazer 440 US 568, at

585 (1979): Malave v Potter 320 F.3d 321, at 326-328 (2003).

${ }^{40}$ See eg, Bushey v New York State Civil Service Commission 733

F 2d 220 (1984) Court of Appeals for the Second Circuit, cert

denied, 469 US 1117 (1985); and Bridgeport Guardians v City of

Bridgeport 933 F 2d 1140 (1991), Court of Appeals for the

Second Circuit.

${ }^{41} 433$ US 321, at 329-330.
}

percentage of non-white (Filipino and native Alaskan) workers in the cannery (non-skilled) jobs and a low percentage of non-whites in the noncannery (generally skilled) positions. The majority rejected this approach, holding that the proper comparison was between the workforce and the relevant labour market. In addition to the quota fear, the majority reasoned an employer would be forced to defend a situation caused by the dearth of skilled non-white applicants, something which is not the employer's fault. ${ }^{42}$ This part of Wards Cove was left untouched by the 1991 Civil Rights Act. There are two technical problems with this particular ruling: (i) fault-based liability and (ii) the rejection of "inhouse" statistics.

\section{(i) Employer's "Fault"}

When discussing the type of comparison to make White, J supported the majority view by stating:

"If the absence of minorities holding such skilled positions is due to a dearth of qualified nonwhite applicants (for reasons that are not petitioners' fault), petitioners' selection methods or employment practices cannot be said to have had a 'disparate impact' on nonwhites."43

In his dissent Stevens, $\mathrm{J}$ reminded the majority that any fault by the employer was irrelevant for liability:

"This statement distorts the disparate-impact theory, in which the critical inquiry is whether an employer's practices operate to discriminate. Eg, Griggs, $401 \mathrm{US}$, at 431. Whether the employer intended such discrimination is irrelevant." 44

This is an accurate criticism, but it does not extend to the true problem. First, Stevens, $\mathrm{J}$ is correct in saying that whether the cause of discrimination is "innocent," or whether the employer is at "fault," is irrelevant to liability. However, the true problem can be illuminated by recalling Griggs. The Court in Wards Cove overlooked a strikingly similar feature common to Wards Cove and Griggs.

In Griggs the use of intelligence tests discriminated against African-Americans because, as African-Americans, they had "long received inferior education in segregated schools." 45 This of course, was not the fault of Duke Power. It was held that the tests caused discrimination. So, in both Griggs and Wards Cove the shortage of "qualified" persons was not the fault of the defendant employer. Yet in

\footnotetext{
42490 US 642, at 652.

${ }^{43}$ Ibid. A similar sentiment was expressed in the context of identifiable practice where White, J feared for "employers being potentially liable for 'the myriad of innocent causes that may lead to statistical imbalances in the composition of their work forces." (Emphasis supplied. Ibid. at 657.)

${ }^{44} 490$ US 642, at 678 .

${ }^{45} 401$ US 424, at 430 .
} 
Griggs it was not an issue whilst the Court in Wards Cove made it one. To take an extreme case, blaming the racial imbalance on the job market was rather like blaming the impact on women of the height and weight requirements in Dothard $v$ Rawlinson ${ }^{46}$ on evolution.

\section{The Rejection of "In-House" Statistics}

A connected reason for rejecting a comparison between members of the workforce was that otherwise an employer would be driven to adopt quotas by the fear of being "haled into court" to justify the situation. ${ }^{47}$ This reasoning is undermined by a number of factors.

First, it assumes that the only alternative to the plantation economy situation is quotas. This is mistaken. Another option is to trace the causes of the disparity. As seen above, this can be achieved when an employer is compelled to justify the situation. ${ }^{48}$ There are many benefits of this approach. Among them is that the causes of the stratification will be traced. Whatever part is within the control of the employer should be solved fairly quickly. Causes beyond the employer's control will at least be identified and then can enter the political arena for possible solutions. Skills shortages, or education deficiencies, peculiar to a particular group, are two examples.

Another factor undermining the majority's reasoning is that it is based on the notion that doing nothing is lawful. Most would agree that employers are under a moral positive duty to ensure that their business practices are not discriminatory. But the majority's reasoning assumes that this does not extend to a legal duty. It has already been argued that this is wrong in relation to acquiescing in subjective hiring practices. But the perversity of the reasoning can be illustrated by considering again Griggs v Duke Power. ${ }^{49}$

In Griggs, the only evidence of discrimination before the eyes of the employer was the racial imbalance of the workforce: African-Americans in the dirty, low paid, outdoor jobs, whilst whites occupied the indoor, higher-wage jobs. If the employer had acted on this, it may have traced the problem to the educational requirements and tests, considered their necessity for the job, and abandoned them. Expensive litigation would have been avoided. Duke Power would not have been "haled into court" or forced to adopt quotas, as White, J suggested. Any employer with a racially imbalanced workforce will either change the culpable practice or justify the situation. In the first case there will be no litigation. In the second, any

\footnotetext{
46433 US 321 (1977).

${ }^{47} 490$ US 642, at 651 .

${ }^{48}$ See eg Enderby $v$ Frenchay HA [1994] 1 All ER 495 ECJ, discussed above.

49 401 US 424 (1971).
}

litigation would be succinct. This is because the only issue would be justification, (the employer having already recognised a prima facie case to justify). The perversity - or perhaps, irony - of the Wards Cove decision, is that by encouraging employers to ignore the signs of discrimination, it will lead to more litigation.

The majority decision is further undermined if the case is compared with Griggs in more detail. What the whole court in Wards Cove overlooked was that the comparisons made in Griggs and Wards Cove were the same. In both cases the comparison made was based upon the racial composition of the existing workforce. ${ }^{50}$ In both cases no comparison was made between the racial composition of the atissue jobs and that of the qualified population in the labour market (the "proper" comparison according to the Court in Wards Cove). ${ }^{51}$ However, in each case the Court presumed that - with this comparison - there was no significant disparity. ${ }^{52}$

So is it possible to distinguish Wards Cove from Griggs? The answer is yes, but in form rather than substance. In Griggs evidence additional to the comparison was presented. The Court noted that in North Carolina, 1960 census statistics show that, while 34 per cent of white males had completed high school, only 12 per cent of African-American males had done so. Regarding the tests, the Equal Employment Opportunities Commission (EEOC) in one case found that use of a battery of tests, including the two tests used in Griggs, resulted in 58 per cent of whites passing the tests, as compared with only six per cent of African-Americans. ${ }^{53}$ This "external" evidence, combined with the comparison, was the basis of Mr Griggs' prima facie case.

There was no "external" evidence of that type in Wards Cove. But there was evidence additional to the comparison. First, Wards Cove Packing recruited its skilled workers using its offices in Washington and Oregon. ${ }^{54}$ This hiring practice had no relationship to any particular required skill. Second, the skilled and unskilled workers were

\footnotetext{
${ }^{50}$ The Court in Griggs noted that out of 95 employees at Duke Power, fourteen were black, all of who worked in the lowest paid labour department. (At 426-427.) It seems to be a common misconception that in Griggs the comparison was made between the applicants. This probably stems from the evidence that blacks were less likely to have a high school diploma and would perform less well in the tests. What seems to have been overlooked is that this evidence was purely external, and was in no way based upon the qualifications or test performances of Duke Power's employees or applicants.

${ }^{51} 490$ U.S. 642, at 650.

${ }^{52}$ In Griggs, it was implicitly accepted when Burger, CJ stated "Because they are [Blacks], petitioners have long received inferior education in segregated schools..." (at 430) and in Wards Cove when White, J talked about the "dearth of qualified nonwhite applicants" (at 652).

${ }^{53} 401$ US 424, at 431, citing CCH Empl Prac Guide, para 17,304.53 (Dec 2nd, 1966).

${ }^{54}$ Note that in US v Georgia Power 474 F 2d 906 (5th Cir 1973), recruitment from predominantly white educational institutions was held to a violation of Title VII (at 926).
} 
accommodated in separate dormitories and mess halls - a practice likely to reinforce any racial disparities. Third, many unskilled workers testified that they actually possessed the necessary skills to fill some of the skilled jobs. ${ }^{55}$ Fourth, there was no promotion from the unskilled to the skilled positions; all skilled jobs were filled solely through the Washington and Oregon offices. The majority simply ignored this evidence. Yet this evidence was substantial. First, overall, it was practically impossible that native Alaskans or Filipinos would be recruited into the skilled jobs and absolutely impossible for a member of the unskilled workforce (nearly all Alaskan or Filipino) to obtain promotion. Second, in any case, it did not need to be the sole basis of a prima facie case; it was only necessary to use it in combination with the comparison of the workforce. Third, it was no less substantial than the additional evidence used in Griggs. (If anything the "vivid" evidence was much more telling.) In Griggs the evidence relating to high school education was state-wide; it did not relate to the local area, which may, or may not have, been exceptional. It also related only to males, which may, or may not have been, typical. Even less certain was the evidence regarding the tests. The Court in Griggs relied on a single EEOC case that based its findings upon a "battery" of tests that merely included the two tests used in Griggs. Yet the Court in Griggs accepted that this evidence, in combination with the comparison of the workforce, formed the basis of a prima facie case.

As far as the comparison is concerned, Griggs and Wards Cove, once undressed, are indistinguishable. The rejection in Wards Cove of the "in-house" comparison amounted to a rejection of Griggs itself. This part of Wards Cove is flawed because it is rooted in fault-based liability and a spurious fear of quotas; and under it, a case like Griggs could not succeed.

\section{The British Position on the Comparison}

In Britain, the new definition demands that the employment practice puts or would put persons of the protected group at a particular disadvantage when compared with other persons. The old definition stated that the comparison should be between those groups who "can comply." This restricted the comparison to positive statistics. For example, in McCausland $v$ Dungannon DC, this restricted the Northern Ireland Court of Appeal ${ }^{56}$ to comparing positive figures of 2.1 and 1.5 per cent. The new definition should allow the use of positive or negative figures, as appropriate.

\footnotetext{
${ }^{55} 490$ US 642, at 674. Stevens, J (dissenting) cited the District Court hearing 34 EPD para 34,437 , at 33,837-33,838. No credit either way was given to this evidence.

${ }^{56}$ By the Fair Employment (NI) Act 1976, which uses the same formula as RRA 1976.
}

So far as the pool for comparison is concerned, the statutory guidance remains unaffected by the new formula for indirect discrimination. Section 3(4), RRA 1976 provides:

"A comparison of the case of a person of a particular racial group with that of a person not of that group ... must be such that the relevant circumstances in the one case are the same, or not materially different, from the other." 57

This does not restrict the comparison to any particular type of pool, and where appropriate, "inhouse" statistics should be acceptable. The issue of "in-house" statistics and quotas has not arisen in the context of the comparison in the UK. There is no rule of law why this should be, but it could be put down to procedure. The British courts, save in redundancy cases, normally accept a theoretical comparison, rather than a real one. This is because real comparisons are impracticable and expensive to make. In the United States most disparate impact cases are class actions, often lasting many years; these justify extensive analysis of the impact of various business practices. In the UK class actions are much less common. ${ }^{58}$ Usually, individuals bring claims of indirect discrimination, although the Commission for Racial Equality or the Equal Opportunities Commission support some claims if it considers that this may be of general benefit. ${ }^{59}$

\section{The Fundamental Flaw of the Quota Fear}

The fundamental reason that recognising these "plantation economy" cases will not lead to quotas is rooted in the symmetrical nature of most antidiscrimination legislation, ${ }^{60}$ which is based on equality, between ethnic minorities and whites, women and men. So, legislation primarily aimed at protecting and benefiting, say, African-Americans, equally protects and benefits whites, and so on and so forth. Thus the adoption of quotas - which would disfavour, say, whites, or men - would be unlawful, and may amount to intentional disparate treatment (direct discrimination), which often will result in higher damages, and so be an even more expensive option. This argument applies to legislation in both jurisdictions. In the United States, in some

\footnotetext{
${ }^{57}$ The relevant provisions for discrimination on the grounds of sex, sexual orientation and religion are materially the same.

${ }^{58}$ For a discussion on the UK position see Pannick, D, Sex Discrimination Law, 1985, Oxford: OUP, pp 284-301.

59 See, for instance, Mandla v Dowell Lee [1983] 2 AC 548 HL. There is also a body of case law where domestic legislation has been challenged (often by the European Commission) for being incompatible with European Union sex discrimination law. Normally, as with Dothard v Rawlinson (see above) these challenges are based upon national statistics.

${ }^{60}$ Exceptions to this principle include pregnancy, disability, and affirmative action.
} 
circumstances, quotas may be unconstitutional as well. ${ }^{61}$

\section{Reasons in Favour of Recognising Plantation Economy Cases}

So far, we have seen that there are no legal reasons why recognising the plantation economy cases would lead to quotas. In addition, there are number of positive reasons why these cases should be recognised. First, the alternative is to do nothing, which should not be an option for a 21 st century civilisation. Second, studies have shown that discrimination causes inefficiencies. ${ }^{62}$ As a matter of common sense, if business practices are tainted by race, gender or any irrelevancies, the employer can hardly tell the shareholders that the business is onehundred per cent efficient. Third, as Lustgarten noted, the more the law can strike down barriers such as discriminatory and unnecessary selection criteria, in Great Britain at least, with its small ethnic minority population, ${ }^{63}$ in purely numerical terms, more unqualified whites stand to benefit than those minorities at whom the legislation principally is aimed. ${ }^{64}$ Fourth, the spur to employers to review their practices more carefully would lead to less discrimination. Fifth, the employer is better placed than anybody to identify the cause(s) of any significant disparity within its workforce.

\section{Reform}

The reform required in the United States is the abolition of section 105, Civil Rights Act 1991. This would leave the phrase "employment practice" in Title VII. Courts would then be left to evaluate whatever evidence is presented when deciding if a plaintiff has a prima facie case. If it is sufficient to raise an inference of a discriminatory practice (which it should have been in Wards Cove), then the employer should be obliged to justify the situation. This will spur employers to monitor the profile of their workforces, and where signs of discrimination are apparent (as in Griggs and Wards Cove), review their employment practices and in doing so, identify the cause(s) of the disparity, as well as perhaps, justify it, or part of it. Note that in practice, this extra burden on employers is non-legal, and should reduce litigation. No legislative reform is necessary in the United Kingdom, although such reform would help clarify matters. Under the new definition, courts should, where appropriate, be able take the same approach and draw an inference of a discriminatory employment practice from significant "in-house" statistics.

\section{Conclusion}

Courts in the United States have always recognised subjective hiring practices except where the employer merely acquiesces in the practice. But this exception has developed in neglect of tortious liability for omissions, and vicariously liability and means that an employer merely can watch his workers engage in discriminatory practices and escape liability. Such a distinction is legally unsound, against the policy of the legislation, and brings the law into disrepute. In the United Kingdom, the reversal of Perera $v$ Civil Service Commission $^{65}$ by the new definition of indirect discrimination opens the way for subjective hiring practices to be challenged. There is no reason why the courts should develop an exception for mere acquiescence.

Recognising plantation economy cases will not lead to quotas because: (1) the symmetrical nature of the legislation, renders quotas unlawful, leaving an employer to face even more litigation; (2) demanding that the plaintiff isolates a causal specific employment practice does nothing to prevent the adoption of quotas, if anything, the element of justification fulfils this role; (3) the element of justification may help identify internal and external causes of racial (or other) stratification; (4) "inhouse" statistics may be used without causing quotas, and indeed were used in Griggs $v$ Duke Power. In addition, we have seen that under Wards Cove, there is likely to be more litigation. In addition there are policy reasons why these cases should be recognised.

In Britain, plantation economy cases should be recognised under the new definition of indirect discrimination. However, claimants should argue carefully to prevent spurious reasoning leading to a misplaced quota fear.

\footnotetext{
${ }^{61}$ See eg Wygant v Jackson Board of Education 476 US 267 (1986).

${ }^{62}$ For an extensive study of business efficiency and Title VII see Greenberger, S, “A Productivity approach to Disparate Impact and the Civil Rights Act of 1991" 72 Oregon Law Rev 253 (1993). Contrast Epstein, R, Forbidden Grounds: The Case Against Employment Discrimination Laws (Cambridge: Harvard University Press 1992), esp pp 226-229.

${ }^{63}$ Estimated at 7.1\% in mid-2000: Social Trends, 2002 , No 32, London: HMSO, Table 1.4, p 30. The estimate includes the Black, Indian, Pakistani, Bangladeshi and Chinese groups. Great Britain excludes Northern Ireland.

${ }^{64}$ Lustgarten, L, Legal Control of Racial Discrimination, 1980, London: Macmillan Press, p 9.
}

${ }^{65}[1983]$ ICR 428 CA. 
International Journal of Diversity in Organisations, Communities and Nations, Volume 4

\section{About the Author}

Michael Connolly lectures in law and specialises in discrimination law and commercial law. He has recently published a book: Townshend-Smith on Discrimination Law (2nd edn.) 2004 (London: Cavendish ISBN 185941-795-7). 